\title{
How to write an integrative review: methodological bases for geriatric nursing
}

\begin{abstract}
Introduction: It is noted that from a biological perspective, aging is marked by progressive changes in cells, tissues and organs that have an impact on the functional capacity of the elderly and provide a more susceptible condition in relation to chronic diseases.
\end{abstract}

Goal: To characterize the content available in the scientific literature about the integrative review and the methodological bases for geriatric nursing.

Method: This is an integrative review of literature, a method whose purpose is to group and synthesize research results on a theme. A survey of 67 articles was carried out, which after passing the exclusion criteria, there were 5 articles for analysis.

Results: The selected publications were arranged in thematic categories worked through the scientific text. Conclusion: The analysis of these studies evidences the importance of the nurse as an active and indispensable member throughout the treatment process and the methodological bases for geriatric nursing.

Keywords: integrative review, nursing, geriatric, elderly
Volume 4 Issue 2 - 2019

\author{
Thayse Luana Farias Costa Ramos, Layla \\ Lívia Maranhão Costa, Jonatha Douglas \\ dos Santos Rocha, Kezia Eunice Costa de \\ Souza, Andreza Maria Gomes de Araujo, \\ Cyndi Myrelle da Silva Barros Romão, Flávio \\ Tenório Mota Viviane Machado de Lima, \\ Francyele Alves da Paixão Nobre, Ingrid \\ Peixoto Veiga Wanderley, Isabella de Almeida \\ Costa Menezes Salles, Caroline Tenório \\ Guedes de Almeida, Joabson dos Santos \\ Lima, Marcella Martins Barbosa Ferreira, \\ Renata França de Melo, Kassiara Ferreira \\ Felix De Lima, Gabrielly Giovanelly Soares \\ Martins, Maila Lorena de Carvalho Sousa, \\ Rayanne Morais de Souza, Patricia Maria da \\ Silva Rodrigues,Flavianne Estrela Maia \\ Nurse, postgraduate in intensive care with emphasis on urgency \\ and emergency, Harvard University, USA
}

Correspondence: Geraldo Vicente Nunes Neto, Department of Nurse, postgraduate in intensive care with emphasis on urgency and emergency, Harvard University, USA, Tel 33333333, Email nursing_harvard@hotmail.com

Received: March 07, 2019| Published: March 15, 2019

\section{Introduction}

Among all the changes and phases of transition that the human being has to face during his or her existence, one of the most feared is the old age, as this has as a specific characteristic the gradual loss of vital capacity. This reality brings with it the fear of dependence, lack of capacity, the confrontations arising from diseases, especially the chronic-degenerative ones and of the death itself. We live in a society that values and, because it does not hurt, it overvalues vitality, beauty, health, which are imposed by aesthetic standards of beauty and yet we dream of formulas capable of maintaining youthfulness. This feature has now become noticeable in our culture. ${ }^{1}$

Throughout the ages the process of aging has been considered differently by several peoples, conforming to their cultural values perceive it in a positive or negative way. The Egyptians considered the old man a troubled life, in which the elders lost their sight, their hearing, and their strength of body, thus being the humility of man. The Greeks treated their old age disdainfully, and preferred to die to grow old. Homer extolled awe, for he associated it with wisdom, as did Socrates and Platon, who through their dialogues showed genuine interest in the problems of old people. Socrates said that for those well-prepared and prudent people, getting old was no problem at all, and Plato considered that old age gave rise to a sense of peace and liberation in each person. ${ }^{2}$

In the first century of the Christian era, Cicero, a philosopher, affirmed that with old age intellectual pleasures go beyond mere bodily pleasures. Here is the quotation that there are men who, like wine, grow old without souring. Goethe, already old at the beginning of the nineteenth century, bequeathed to mankind a message of self as to old age, for he declared that the old man should not fall for years, even with his white hair should not lose the hope of finding him love. ${ }^{3}$

Aging can be associated with the loss of health, physical capacity, the installation of pa-tological processes and other factors that help the human being to feel frustrated in the face of this reality, since irreversibly deformed daily, becoming clear and unequivocal the characteristic changes and limitations of this time of life. This process is defined as a set of changes experienced by the body from birth to death. Also, according to sociologists and epsychologists, there are changes independent of processobiological, such as social, psychological, and spiritual, which are as important as the biological aspect in the aging process. ${ }^{4}$

The biological process is natural, dynamic and progressive, and its evolution causes changes in the organism. Morphologically, changes will occur by the appearance of changes in body shape, characterized by the presence of wrinkles, white hairs, among others. Physiologically, the alterations are related to the diminution of organic functions, and biochemically aging is evidenced by the changes in glial activity and the deterioration of the mechanisms of organism synthesis, especially of the protein synthesis that is impermissible for the maintenance of the vitality of the human organismo. ${ }^{5}$

Therefore, the purpose of this study is to reflect on how to write an integrative review and the methodological bases for geriatric nursing. 


\section{Method}

The present study was an integrative literature review. This method has the purpose of grouping and synthesizing research results on a given topic, in an organized way so that it contributes to a deepening of the knowledge about the question addressed. This method has been used in the production of articles, dissertations and theses in the health area in recent decades. ${ }^{6}$

An integrative review of the literature on scientific production based on geriatric nursing, in the national and international context, was carried out in the health area. This method allows "... the search, the critical evaluation and the synthesis of the available evidence of the subject investigated.... ${ }^{7}$ The use of this method allows, as a result, the current knowledge situation on the topic addressed, the implementation of interventions in health care and the identification of gaps that need to be deepened in the subject. ${ }^{8}$

For the elaboration of this study, the six stages of the integrative review were used, as cited by Mendes, Silveira and Galvão (2008) in order to organize the information collected. ${ }^{9}$

1st stage: elaboration of the guiding question. Its definition is the most important phase because it determines the identification of what should be approached to contemplate the proposed theme.

2nd stage: search or sampling in the literature. The search was carried out in a wide and diversified way in the reliable databases, taking into account that the determination of the inclusion and exclusion criteria for material selection should be carried out in accordance with the guiding question.

Step 3: data collection. At this stage we defined what would be extracted from the selected studies through the use of a previously elaborated instrument, with the purpose of organizing the key information in a concise way to construct the study.

Step 4: Critical analysis of included studies. At this stage the data analysis was performed in detail to ensure the validity of the review. Always taking into account the guiding question as the basis for any analysis.

Step 5: discussion of results. In this phase, the results obtained in the research were discussed and a critical analysis was performed on what was evidenced.

Step 6: presentation of the integrative review. This is the phase where the study was properly drafted. Containing enough information for the reader to make an analysis of the study performed. To guide this integrative review the following question was elaborated: what scientific knowledge is available in the literature about the therapeutic methods of geriatric nursing?

The data of the studies included in the research were categorized, analyzed and discussed, establishing relationships with the theoretical basis in focus.

\section{Results and discussion}

It is possible to define the aging process in different ways, depending on the object of interest, or the research field to which it is proposed. By virtue of this, varied theories have arisen about the biological process of desensitization, biological theory, the theory of free radical crosslinking, autoimmune reactions and the use and depletion of the human body over time. However, we will describe the biological theory, the process of homeostatic balance and the psychosocial theory of subculture. ${ }^{10-12}$

The theory of biological aging, another way of assessing the aging process, conceives the idea that human beings are born with a preset genetic schedule, or with a biological clock, and it is considered that human cells reproduce themselves, the number of genetic divisions is reduced to a certain number, since through the genetic program they also have a limited number of cell divisions. ${ }^{13-15}$

In subculture theory, it is considered that the elderly have norms, beliefs, attitudes, expectations and behaviors of their group that differ completely from other groups of people characterizing it as a subculture, distancing it from other groups of bands different, and often leading to some gross segregation by Society. ${ }^{16-18}$

These considerations regarding the plurality of the peculiar aspects that involve the process of aging in all the dimensions of the human being have awakened us to write this article that aims to proceed to a reflection about the nursing care in the light of the transcultural theory of Madeline Leininger and suggest model of care, aiming at appropriating more appropriate care for the elderly. ${ }^{19}$

Corroborating with the thought of the need and importance of contextualizing the aging process turned to cultural issues, it is essential to introduce in this point the theory of Medeleine Leininger, a North American nurse, who developed the Transcultural Theory, also known by the terms: ethno - Nursing or cross-cultural nursing. The Transcendental Theory was defined by Leininger as "the study of the beliefs, values and practices of nursing care, as perceived and cognitively known by a certain culture through its direct experience, beliefs and value system". ${ }^{19}$

The author observed that the lack of recognition of the importance of cultural factors in the human being results in a gap in the planning of nursing care, as if there was a lack of a link that links the past life of the individual with current life [19]. Although it is a transcultural phenomenon, since it reaches people of different nationalities and cultures, the aging process has its own characteristics, but rather the acculturation of each person, that is, a process of which the members of each group adapt or learn to adapt through the behavior of other groups. From the point of view of aging, the individual will face an adaptation to the process of evolutionary degeneration of the organism, and also, often, will need to adapt to the younger members of the family, as a way to address some family need. ${ }^{19}$

Taking care of the cultural diversity of the naive means valuing the customs diffused by the native culture of each people. These customs are impregnated definitively in each ethnic group and are very difficult to eradicate them, since the groups develop characteristics similar to their history, language and cos tumes, as they usually share the same beliefs about aging. Ethnic groups have burned to other countries, they maintain a link between them and the world, and the cultural norms of these ethnic groups end up influencing diet, the form of pain, adherence to medical treatments and activities self-care. ${ }^{20}$

\section{Conclusion}

Analyzing the studies used in this integrative review, it is concluded that the nurse professional as an active member of the multiprofessional team is of great importance, since it becomes the main link between the patient and the other professionals during the foundation for the performance of the methodological bases in 
geriatric nursing. These patients undergoing treatment and followup of the geriatric nursing team need special care, which demands greater attention due to their health conditions. It is hoped that the results of this literature review may contribute to awakening in the geriatric nursing team the importance of a targeted assistance for the prevention, recovery and promotion of the elderly population.

\section{Acknowledgments}

None.

\section{Conflicts of interest}

No conflict of interest has been declared by the author.

\section{References}

1. Almeida WA, Ferreira AM, Ivo ML, et al. Fatores associados à qualidade de vida de pessoas com feridas complexas crônicas. $J$ res fundam care. 2018;10(1):9-16.

2. Brito CCB, Cibelly ASLF, Karina OM, et al. Envelhecimento populacional e os desafios para a saúde pública: análise da produção científica. Rev Kairós Gerontol. 2013;16(3):161-178.

3. Cruz RAO, Nóbrega VKM. Produção científica de enfermagem sobre úlcera venosa: uma análise bibliométrica brasileira. Revista de Enfermagem. 2016.

4. Fonseca C, Franco T, Ramos A, et al. A pessoa com úlcera de perna, intervenção estruturada dos cuidados de enfermagem: revisão sistemática da literatura. Rev esc enferm. 2012;46(2):480-486.

5. Hall J, Buckley HL, Lamb KA, et al. Point prevalence of complex wounds in a defined United Kingdom population. Wound Repair Regen. 2014;22(6):694-700

6. Instituto Brasileiro De Geografia E Estatística (IBGE). Censo demográfico; 2010.

7. Leite DG, Souza MC, Maximino DAFM, et al. The family health support core (nasf) and health practices: are there many challenges to be overcome?. International Archives of Medicine. ISSN 17557682;2017(10).

8. Mendes KDS, Silveira RCCP, Galvão CM. Revisão integrativa: método de pesquisa para a incorporação de evidências na saúde e na enfermagem. Texto e contexto enferm, Florianópolis. 2008;17.
9. Santos LSF, Camacho ACLF, Oliveira BGRB, et al. Influência da úlcera venosa na qualidade de vida dos pacientes: revisão integrativa. Rev enferm UFPE on line. 2015;9(Supl. 3):7710-7722.

10. Sellmer D, Carvalho CMG, Carvalho DR, et al . Sistema especialista para apoiar a decisão na terapia tópica de úlceras venosas. Rev Gaúcha Enferm Porto Alegre. 2013;34(2):154-162.

11. Silva MH, Jesus MCP, Merighi MAB, et al. Limites e possibilidades vivenciados por enfermeiras no tratamento de mulheres com úlcera venosa crônica. Rev Esc Enferm USP. 2014;48(Esp):54-59.

12. Souza MKB, Matos IAT. Percepção do portador de ferida crônica sobre sua sexualidade. Rev Enferm UERJ. 2010;18(1):19-24.

13. Tavares TCA, Gomes DCN, Capistana TRS, et al. Sistematização da assistência de enfermagem a um paciente portador de úlcera venosa: relato de experiência. anais do v congresso de educação em saúde da amazônia (coesa), universidade federal do pará -8 a 11 de novembro de; 2016.

14. Teixeira I, Guariento ME. Biologia do envelhecimento: teorias, mecanismos e perspectivas. Ciênc Saúde Coletiva. 2010 15(6):28452857.

15. United nations department of economic and social affairs (undesa), population division. world population prospects: the 2012 revision. highlights and advanced tables. working paper No. ESA/P/WP/. 228. New York: United Nations; 2013;94 .

16. Veras RP, Caldas CP, Cordeiro HA, et al. Desenvolvimento de uma linha de cuidados para o idoso: hierarquização da atenção baseada na capacidade funcional. Revista Brasileira de Geriatria e Gerontologia. 2013;16(2):385-392.

17. Mendes EV. As redes de atenção à saúde Brasília: Organização PanAmericana da Saúde; 2011.

18. Moraes EM. Atenção à saúde do idoso: aspectos conceituais Brasília: Organização Pan-Americana da Saúde; 2012.

19. Veras RP, Oliveira MR. Care pathway for the elderly: detailing the model. Revista Brasileira de Geriatria e Gerontologia. 2016;19(6):887-905.

20. Veras RP. Experiências e tendências internacionais de modelos de cuidado para com o idoso. Cien Saude Colet. 2012; 17(1):231-238. 